\title{
Henri J. M. Nouwen's look at pastoral work
}

Henri J. M. Nouwen was an outstanding scientist. The spirituality was the field that interested him the most. He shows pastoral care also in this light. His critical look at pastoral work, but above all valuable guidance, deeply rooted in spirituality, with concern for man, is also valid today.

Key words: the spirituality of the priest, preparation for the priesthood, individual ministry, preaching, formation of the community, celebration.

\section{Introduction}

Henri J. M. Nouwen's life path and scientific preparation (1932-1996) shed light on his scientific views, his attitudes towards life, empathy for the needy, his involvement in social affairs.

This is indicated by his biography. Henri J. M. Nouwen was born in 1932 in the Netherlands to a deeply Catholic family. His uncle, Toon Ramselaar, was a Catholic priest in the Diocese of Utrecht. Henri first studied at the Jesuit Alojsius College in the Hague, then at the Rijesenburg Theological Seminary. He was ordained a priest on 21 July 1957 for the Diocese of Utrecht. Then, between 1957 and 1964, with the approval of Cardinal Alfrink, he studied psychology at the Catholic University of Nijmegen, and particularly the basis of clinical psychology. In his dissertation he focused on the views of A. Boisen, an American scientist, founder of the movement for clinical pastoral education. This direction of H. Nouwen's interest began to dominate in his views and publications. Hence his interests revolved around psychology, pastoral care, spirituality, social justice and community. 
Thanks to his knowledge of psychology he tried to combine the spirituality of the pastor with modern psychology. It is worth mentioning that Henri Nouwen had been a lecturer of the pastoral theology from 1971-1981 at the Yale Divinity School for ten years. In those years he stayed at the Genesee Trappy Abbey in New York State, which resulted in his illustrated illustrations in the form of prayers in the memoirs The Call of Mercy. Prayers of Genesee. ${ }^{1}$ Since 1986, he has lived with the handicapped community at LArche Daybreak in Richmond Hill for ten years. He was there through his acquaintance and friendship with Jean Vanier, the founder of the Ark, a community referring to the biblical Noah's Ark.

Henri J. M. Nouwen in many publications and publications about his work is closely linked to spirituality, as evidenced by his approximately 40 works in this field. Meanwhile his education and his earliest university studies indicate his pastoral interests. Especially since his publications on Christian spirituality are linked to their practical application in pastoral work. Another proof of his pastoral interest is that there are several items that directly address the field of ministry, of course in his view and in his vision. These are: Creative ministry ${ }^{2}$, In the name of Jesus ${ }^{3}$, The Way of the heart. Connecting with God through prayer, wisdom, and science ${ }^{4}$.

\section{Nouwen's remarks on preparing for pastoral work}

Henri Nouwen's Creative Pastoral Work presents pastoral activity in four important pillars: the preaching of God's Word - preaching, individual pastoral care, community formation - organization and celebration - liturgy. There are three functions of Christ in this division: prophetic - proclamation of the word of God, priesthood - celebration and pastoral - the Christian community through its good organization. Nouwen emphasizes the fourth pillar of pastoral activity, namely individual ministry. This latter pillar clearly refers to his knowledge and practice of clinical psychology. This pastoral practice is widely

1 Henri J.M. Nouwen, A Cry for Mercy. Prayers from the Genesse; Polish ed., Poznań 1993.

Id., Creative Ministry, 1st ed. 1971, the latest ed. 2003.

$3 \quad$ Id., In the Name of Jesus. Reflections on Christian Laedership, Nowy Jork 1989; Polish transl. Wimię Jezusa, Kraków 2004. German ed. has a meaningful title: Seelsorge, die aus dem Herzen kommt, Christliche Menschenfuehrung in der Zukunft, Freiburg 1989

$4 \quad$ Id., The Way of the Heart, cop. 1981; Polish ed. Droga serca. Duchowość $i$ dzisiejsze duszpasterstwo, Kraków 2008. 
practiced in the United States, Anglo-Saxon countries and Western Europe. It is, in fact, counseling used in many directions, but always about helping people who need spiritual strengthening, pointing to difficult life problems, etc.

However, in order to fulfill these pastoral tasks properly, they must be properly prepared. Nouwen says at the outset of his reflections on the above-mentioned pastoral pillars of proper preparation in the theological seminaries. He points out how great Christianity can be when it comes to spreading education, because in the past centuries, the teaching was one of the most popular and respected roles of the Christian clergy. Wherever the Christians went to serve the people, they treated teaching as their primary task. They were convinced that the path to new freedom and a new way of life would be opened up by the rise in the level of teaching people and their knowledge of themselves and the world ${ }^{5}$. In the meantime, as our writer emphasizes, the lack of sufficient spiritual foundation during seminary studies may adversely affect the later work of priests. He points out where these deficiencies come from. First and foremost, most of the seminaries have given up the permanent framework of spiritual exercises that have been the basis of the day-to-day preparation of the priesthood. Students had constant hours of meditation, common prayers, and regular Masses, prescribed as obligatory, since they were considered as an important part of this sanctifying life that they should be conscious. It was emphasized that only such intensive life of prayer can protect individual students from the many dangers of the world and that no priest could work in the long run fruitfully if he did not keep up with the exercises that the whole clergy generations served as their supporters in their hardworking life. ${ }^{6}$

The times have changed, but the life of priests has been subjected to new demands and ways of working. Henri Nouwen, as a watchful observer of pastoral activity, sees an ever-weaker connection between the time devoted to pious exercises and the daily pursuit of the priest. Taking care of various things, faced with a great number of classes, priests feel so burned many times that even the spiritual exercises brought up during the seminary classes do not bring them practical solutions for the good of the parishioners, frustration can become almost everyday bread. Nouwen explains the internal problem of the priest that his concern for his parishioners can not be just his activity

Id., Creative Ministry, 10-11.

Nouwen assesses this situation in the teaching that occurred in the $70 \mathrm{~s}$ of the last century: the process of liberalization, individualisation, etc. 
at various levels of social life. Pastoral care is to be more than care. It is necessary to address the inner problems of man. It is here in view above all the critically contemplation of human condition. With the help of this contemplation, the priest can remove the veil and show the facts precisely to his and other eyes that good and evil are not only words, but visible things in every person's life. In this sense, every pastoral contact becomes a challenge to a better understanding of God's work in man so that with increasing sensitivity one can distinguish light from the darkness in the human heart. The contemplation thus seen is not only an important aspect of the priest's life, it is an indispensable condition for fruitful pastoral work. Pastoral care is contemplation. Hence, it is never possible to limit individual apostolate to a certain skill or technique, since pastoral ministry is ultimately about continually seeking God in the life of the person we want to serve. The paradox of pastoral ministry lies in the fact that when we want to bring people closer to God, we must first find Him in the life of this $\operatorname{man}^{7}$.

\section{About the credibility of the priest}

If the priest wants to be useful in his relations with people, he must be professionally prepared, that is to have a professional education and a unique ability to serve man. Faced with today's problems of the world of manipulation, it must go beyond purely professional capacity and become, by self-denial and contemplation, a credible witness of the covenant of God with mankind.

A good priest is called to develop his skills without pretending to be a unique professional. If he has the ability to renounce himself, be open and honest, and understand the meaning of human suffering, then he can mediate with the person he cares about, in the sense that God himself is the one who uses his servants' hands to reveal his delicate love.

Henri Nouwen emphasizes the great importance of the in-depth spirituality of the pastor. The pastoral model can serve the spirituality of the desert, which Nouwen writes in The Way of the Heart ${ }^{8}$. Nouwen understands the desert not in terms of seclusion, according to him, it is the destiny of some time and place to stay with God and only with God. He says, "The concrete shape of the hermit's regulations will be

H. Nouwen, Creative Ministry, p. 5-8.

8 H. J. M. Nouwen The Way of the Heart: Connecting with God Through. Prayer, Wisdom and Silence, [cop. 1981]; the latest ed. 2003; Polish ed: Droga serca. Duchowość pustyni i dzisiejsze duszpasterstwo, Kraków 2006. 
different for each person, depending on its character, pastoral and environment"9. But the desert is also a place of struggle and a great meeting - fighting the desire for false "I" and meeting the loving God who gives self as the substance of the new "I". The priest needs this desert, as much of his ministry is limited by the pitfalls of his own judgments. These constraints created by us do not allow the priest to be at the disposal of the people and to end our mercy ${ }^{10}$. So such a desert cleanses the priest of his own self and makes him more accessible to the good of the people.

But what is the task of the priest in the complicated field of modern society? This is most apparent in the proclamation of the Word of God. Preacher is to show the listener their longing for God, to see God who can solve their problems, to teach confidence to God. Preacher is to bring dialogue with the listeners, share their experiences with them ${ }^{11}$.

\section{The ability to organize parish life}

$\mathrm{H}$. Nouwen postulates the good organization of parish life so that the priest does not take full responsibility for many specific parish projects, but to skillfully entrust many things to people in their parish and personal responsibility for the community. The special, unchangeable task of the priest could be to direct people's attention to their hidden abilities, to connect the various private matters to the affairs of the community, to give people a vision that opens their eyes to their social responsibility and inspires them to build a Christian community of faith over many individual actions. The priest would be the organizer of the event. He can arouse in his environment dormant abilities. He can also break pessimism, may face collective depression and arouse human consciousness that one can change the interpersonal relationships better than the ones that are at the moment. The pastor can warn people against apathy if they are disappointed again and run into destructive forms instead of doing something constructive. He can help build an attitude of hope and certainty that makes the community more receptive and adaptable to new situations and is constantly looking at new opportunities and prospects ${ }^{12}$.

9 Id, Droga serca. Duchowość pustyni i dzisiejsze duszpasterstwo, Kraków 2008, p. 32 .

10 Cf. Id., p. 37.

11 Id., Creative Ministry, p. 48-49.

12 Id., p. 75-76. 
In the meantime, it is still a great exception that the parishes routinely discuss common tasks, analyze and evaluate them, and are developed in any form of strategy or far-reaching planning. The second issue emphasized by $\mathrm{H}$. Nouwen, which influences the functioning of the parish, is that laity are rarely or at all invited to be actively engaged in pastoral work. At the same time, many priests are complaining about overwork by visiting sick and elderly people, chairing meetings, managing finances and other matters in their parishes, and failing to appreciate the fact that true leadership personality is also expressed through skilful delegation to others. Another third reason for the parish's failure is that parishes mostly understand themselves as small kingdoms. This applies especially to the parishes of the city. If clergy and laity from different parishes regularly meet, they discuss their common problems, involve their various talents, exchange ideas, coordinate their intentions, and sketch common plans for teaching, sermons, pastoral work and financial management; If they critically address the main problems of their city and, as the need arises, collectively, and people understand that the Christian community is involved in everyday problems, then the Church cannot be unnoticed ${ }^{13}$.

H. Nouwen's above remarks, regarding the proper organization of the parish, are quite right, but they were made shortly after the Second Vatican Council, when the collegiality began to shape itself among the clergy and the lay faithful. Both diocesan and parish councils began to function, depending on the needs and aspirations of both priests and lay people. It happens that the meetings and deliberations of these groups are sporadic, but there is a special tool that enables them to listen to the postulates and their fulfillment in the lives of Christians.

\section{On individual ministry}

As one of the important pastoral pillars, Henri J. M. Nouwen considers individual pastoral care commonly understood as individual counseling. H. Nouwen talks about the deep connection of individual pastoral care with the priestly spirituality. He further says that if a priest finds that he is able to give people life, if he is able to see without fear of their real state, then at the same time he ceases to treat himself as someone living in the margins of reality, rather he knows that he is at the center of reality ${ }^{14}$. At the same time, Nouwen emphasizes that in order to be able to serve people in this way, especially in individual

\footnotetext{
13 See id., p. 92-93.

$14 \quad$ Cf. id., p. 54.
} 
counseling, it is necessary to be prepared, educate students so that they can listen to what problems people have; teach in such a way that the future priest to be aware that it will be more necessary than it is supposed to be when people ask about the meaning of life. Then he will need special empathy. Such an attitude requires the priest to self-denial: "Then Jesus said to his disciples, 'If anyone wants to be a follower of mine, let him renounce himself and take up his cross and follow me. Anyone who wants to save his life will lose it; but anyone who loses his life for my sake will find it. What, then, will anyone gain by winning the whole world and forfeiting his life? Or what can anyone offer in exchange for his life?" (Mt 16: 24-25). The point is not to put yourself on a pedestal, or to be an expert in all walks of life. H. Nouwen, referring to A. Boisen, gives his advice for the priest: "What can I learn from the man I met as a priest?"15.

Pastoral concern is more than care. It is primarily concerned with the cautious and critical contemplation of human condition. With the help of this contemplation, the priest can remove the veil and show the facts precisely to his and other eyes that good and evil are not only words, but visible things in every person's life. In this sense, every pastoral contact becomes a challenge to a better understanding of God's work in man so that with increasing sensitivity one can distinguish light from the darkness in the human heart ${ }^{16}$.

The contemplation seen in such a way is not only an important aspect of the priest's life, it is an indispensable condition for fruitful pastoral work. Pastoral care is contemplation. Hence, it is never possible to limit individual apostolate to a certain skill or technique, since pastoral ministry is ultimately about continually seeking God in the life of the person we want to serve. The paradox of pastoral ministry is in fact when we want to bring people closer to God, we must first find Him in the life of this man.

\section{Celebration - Liturgy}

One of the most important tasks of the priest is to celebrate sacred rites through the liturgy. Henri Nouwen devotes to this issue one chapter of his Creative Ministry. It is surprising and very interesting, to take this issue. Each of his pastoral reflections addresses the issue of spirituality. This also happens with the understanding of celebration. Celebrating according to him, is listening to the voice of both the voice

$15 \quad$ Id., p. 69.

$16 \quad$ Id, p. 70. 
of nature, the work of God's creation, to have eyes and ears open to man and above all to hear God himself. God speaks in His Word, and does so in a special way in the liturgical rites. Nouwen emphasizes that in celebrating both human and celebrating the liturgical celebrations of the Church there are three elements: the realization of the past, the present, and of course, the future. All these temporal terms have great significance for human celebration. $\mathrm{H}$. Nouwen proposes, from every age of life, to hope and to see God's presence there.

On the basis of what $\mathrm{H}$. Nouwen said about celebrating, you can make further thoughts. At the very celebration of the festival there are these Nouwen's three elements, which are included in religious celebration, namely, historical, present and future. Every human celebration celebrates something that has already existed in time, something that is worth mentioning, highlighting, in a word worth celebrating. The moment of the present is a sure departure from everyday reality, a transfer - we would say - into another extraordinary reality, into a utopia, but it is possible to forget about daily troubles, and also to be able to rejoice in despite the past and uncertain future, daily life and everyday activity. This aspect indicates that at least for some time we are ourselves in celebrating ${ }^{17}$. This has the positive effect that, after authentic celebration, we return to reality, to the daily work being relaxed, renewed and spiritually enriched. Celebration is therefore not detached from everyday reality. Celebration also serves the future. And this is the third element of celebration - the future. These three elements can be seen in every celebration, especially in religious celebrations, because in it we remember the works of the Lord, his memorial, we also celebrate his living presence especially in the Eucharist, as the whole community participates in it and prepares us for a renewed life in everyday life.

It must also be stated that celebration is one of the essential needs of man, both physically and psychologically. There is necessity for Christian celebration, in order to fulfill harmony with the image and the likeness of God for man, is due to the inner spiritual nature of man. But the desire to celebrate and celebration itself, however, is done together with others, that is, a man should celebrate in the society, in the community. The community is of great importance to people. It is created by the participation in the Eucharist; communities form small groups of prayer or evangelization in which the Christian finds

17 H. Cox, Das Fest der Narren. Das Gelaechter ist der Hoffnung letzte Waffe, Guetersloh 1977, p. 66; (I used German translation, meanwhile the subtitle of English edition better reflects the contents of the book: The Feast of Fools. A Theoligical Essay of Festivity and Fantasy). 
himself, as a believer, and as a person treated in a way that is adequate to his person. Celebration is a community experience of the Kingdom of God for a Christian. Celebrating the Kingdom of God here and now is a testament to the new time and new life to which all human beings are striving for with their subconsciousness. The last popes confirm this aspect. Pope Benedict XVI highlights the unifying aspect of the Eucharist, since participation in the Sacrifice of Jesus, participation in his Body and Blood, becomes a union of believers with Christ. As Benedict XVI says: "The mystery of this sacrament is of a social character, in sacramental communion, for I am united with the Lord, just like all other people who receive communion" (1 Cor 10: 17) ${ }^{18}$. Benedict XVI also emphasizes the communal nature of the Eucharist in the Post-Synodal Exhortation Sacramentum Caritatis on the Eucharist when he says that the Eucharist continues the existence and activity of the Church. In the Eucharist there is an inseparable bond between Christ and the Church. It is significant that the Second Eucharistic Prayer calling for the Holy Spirit says "for the Holy Spirit to unite us all who receive the Body and Blood of Christ" 19 .

In addition, through this eucharistic and spiritual celebration, a person experiences liberation, emphasizing his dignity as a divine child, fulfilling his desires for the enjoyment of authentic and full human freedom ${ }^{20}$. It builds a human future, built on faith in God.

\section{Conclusion}

Henri Nouwen directs attention in his reflections on pastoral care, on the priest, on the spirited priest, having a good knowledge of the human psyche, recognizing his needs and being open to man at all. Hence his reflections on various areas of pastoral ministry including preaching, parish pastoral work, liturgy, and especially individual pastoral care, are based on deep human knowledge. He had theoretical and practical preparation in this respect, as he studied clinical psychology as well as staying in the Trappist monastery, and he gained special experience from working with impaired people at Daybreak in Canada. This was the most evident in his work In the Name of Jesus. Reflections

18 Benedict XVI, Encyclical Letter Deus caritas est of Christian love, Kraków 2006, no. 13-14.

19 Id., Post-Synodal Apostolic Exhortation on the Eucharist as the Source and Summit of the Church's Life and Mission, Kraków [cop. 2007], no. 15.

20 See I. Tokarczuk, Niedziela tworzy Kościót, in: II Krajowy Kongres Eucharystyczny $w$ Polsce, Warszawa 1988, issue 2, p. 32. 
on Christian Leadership, the German translation of this work gives a significant title, close to the meaning of the author: "The pastoral ministry that flows from the heart. Guiding people in the future."21 Henri Nouwen's writings do not lose value and today, man remains a bodily creature with his psyche as well as a spiritual being. The wise guidance of the faithful to God is an important and responsible task, so it is possible to draw much from Henri J.M. Nouwen's reflections.

\section{HENRI J. M. NOUWENA SPOJRZENIE NA DUSZPASTERSTWO}

Henri J.M. Nouwen był wybitnym naukowcem. Dziedziną, która go najbardziej interesowała, była duchowość. W jej świetle przedstawia również duszpasterstwo. Jego krytyczne spojrzenie na duszpasterstwo, ale przede wszystkim cenne wskazówki, przeniknięte głęboką duchowością, z troską o człowieka, są aktualne także dzisiaj.

Słowa kluczowe: duchowość duszpasterza, przygotowanie do kapłaństwa, duszpasterstwo indywidualne, kaznodziejstwo, prowadzenie wspólnoty, świętowanie.

\section{Bibliography:}

1. Benedict XVI, Encyclical Letter Deus caritas est of Christian love, Kraków 2006.

2. Benedict XVI, Post-Synodal Apostolic Exhortation on the Eucharist as the Source and Summit of the Church's Life and Mission, Kraków [cop. 2007].

3. Cox H., Das Fest der Narren. Das Gelaechter ist der Hoffnung letzte Waffe, Guetersloh 1977.

4. Nouwen Henri J.M., A Cry for Mercy. Prayers from the Genesse; Polish ed., Poznań 1993.

5. Nouwen Henri J.M., Creative Ministry, 1st ed. 1971, the latest ed. 2003.

6. Nouwen Henri J.M., In the Name of Jesus. Reflections on Christian Laedership, Nowy Jork 1989.

7. Nouwen Henri J.M., W imię Jezusa, Kraków 2004.

8. Nouwen Henri J.M., Seelsorge, die aus dem Herzen kommt, Christliche Menschenfuehrung in der Zukunft, Freiburg 1989

9. Nouwen Henri J.M., The Way of the Heart, cop. 1981.

10. Nouwen Henri J.M., Droga serca. Duchowość i dzisiejsze duszpasterstwo, Kraków 2008.

11. Tokarczuk I., Niedziela tworzy Kościót, in: II Krajowy Kongres Eucharystyczny $w$ Polsce, Warszawa 1988.

21 H, J. M. Nouwen, Seelsorge, die aus dem Herzen kommt. Christliche Menschenfuehrung in der Zukunft, Freiburg im Breisgau 1989. 